\title{
Leptin and Cancer: Updated Functional Roles in Carcinogenesis, Therapeutic Niches, and Developments
}

\author{
Tsung-Chieh Lin ${ }^{1}(\mathbb{D}$ and Michael Hsiao $2,3, *$ (D) \\ 1 Genomic Medicine Core Laboratory, Department of Medical Research and Development, \\ Chang Gung Memorial Hospital, Linkou 333, Taiwan; tclin1980@cgmh.org.tw \\ 2 Genomics Research Center, Academia Sinica, Taipei 115, Taiwan \\ 3 Department of Biochemistry, College of Medicine, Kaohsiung Medical University, Kaohsiung 807, Taiwan \\ * Correspondence: mhsiao@gate.sinica.edu.tw; Tel.: +886-2-27871243; Fax: +886-2-27899931
}

check for updates

Citation: Lin, T.-C.; Hsiao, M. Leptin and Cancer: Updated Functional Roles in Carcinogenesis, Therapeutic Niches, and Developments. Int. J. Mol. Sci. 2021, 22, 2870. https:// doi.org/10.3390/ijms22062870

Academic Editor:

Víctor Sánchez-Margalet

Received: 12 February 2021

Accepted: 10 March 2021

Published: 11 March 2021

Publisher's Note: MDPI stays neutral with regard to jurisdictional claims in published maps and institutional affiliations.

Copyright: (c) 2021 by the authors. Licensee MDPI, Basel, Switzerland. This article is an open access article distributed under the terms and conditions of the Creative Commons Attribution (CC BY) license (https:/ / creativecommons.org/licenses/by/ $4.0 /)$.

\begin{abstract}
Leptin is an obesity-associated adipokine that is known to regulate energy metabolism and reproduction and to control appetite via the leptin receptor. Recent work has identified specific cell types other than adipocytes that harbor leptin and leptin receptor expression, particularly in cancers and tumor microenvironments, and characterized the role of this signaling axis in cancer progression. Furthermore, the prognostic significance of leptin in various types of cancer and the ability to noninvasively detect leptin levels in serum samples have attracted attention for potential clinical applications. Emerging findings have demonstrated the direct and indirect biological effects of leptin in regulating cancer proliferation, metastasis, angiogenesis and chemoresistance, warranting the exploration of the underlying molecular mechanisms to develop a novel therapeutic strategy. In this review article, we summarize and integrate transcriptome and clinical data from cancer patients together with the recent findings related to the leptin signaling axis in the aforementioned malignant phenotypes. In addition, a comprehensive analysis of leptin and leptin receptor distribution in a pancancer panel and in individual cell types of specific organs at the single-cell level is presented, identifying those sites that are prone to leptin-mediated tumorigenesis. Our results shed light on the role of leptin in cancer and provide guidance and potential directions for further research for scientists in this field.
\end{abstract}

Keywords: leptin; prognosis; cancer progression

\section{Introduction}

Leptin $(L E P)$, a protein hormone secreted by adipose tissues, primarily functions as the ligand of leptin receptor ( $L E P R)$ to regulate appetite and energy expenditure [1,2]. Leptin plays critical roles in the modulation of processes involving in the hormones synthesis, blood pressure, reproduction, osteogenesis, hematopoiesis, angiogenesis, and immunity [3]. Moreover, leptin is also uncovered to participate in the pathophysiology of energy metabolism [4], endocrine diseases [5], neurovascular diseases [6], or obesity and metabolism-associated diseases [7]. Leptin is encoded by the OB gene on chromosome 7. The 2 LEP isoforms and 6 LEPR isoforms are shown with the protein domains indicated (Figure 1). The leptin receptor, encoded by LEPR, is a member of the class 1 cytokine receptor family and has been indicated to play critical roles in the pathogenesis of many malignant cancer types $[1,8,9]$. The downstream effects of leptin signaling can induce malignancies via the activation of specific signaling pathways in cancer cells [10-12]. Recent studies indicate that leptin receptors are highly abundant in many cancer types [13-15]. Accumulated experimental results have highlighted the role of leptin-leptin receptor signaling in promoting several processes linked to cancer progression, including cell proliferation, metastasis, angiogenesis and chemoresistance [16-19]. In this review article, we integrate and summarize the current literature on this topic, focusing on evidence demonstrating leptin/leptin receptor expression levels in a broad range of cancer types together with its 
biological effects on the regulation of several critical processes related to cancer progression. In addition to the biological function of the leptin axis in cancer, its clinical and prognostic significance in multiple cancer types is illustrated.

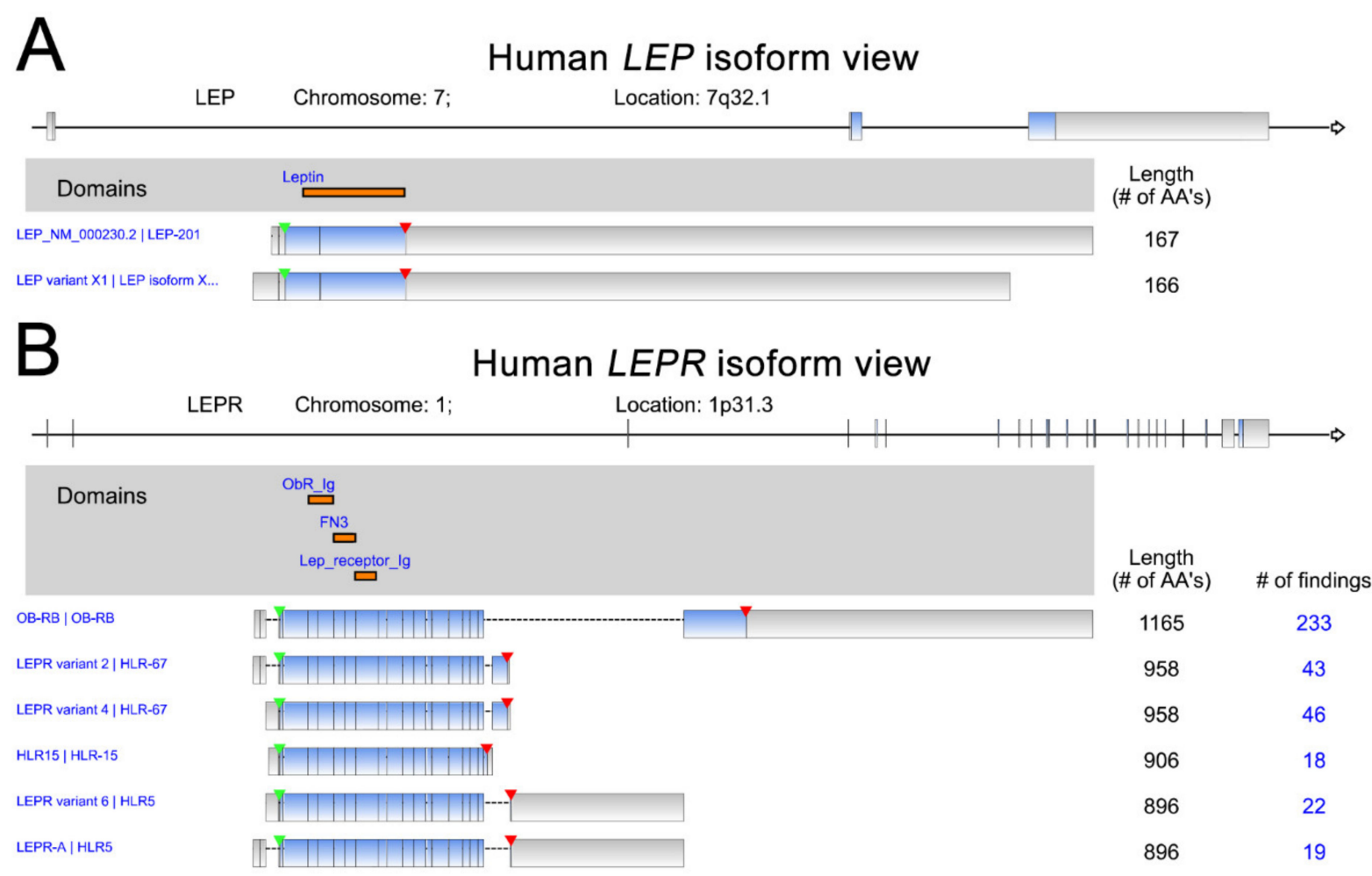

Figure 1. Human LEP (A) and LEPR (B) isoforms. The data were retrieved and analyzed from RefSeq. The protein domains of various isoforms are indicated in orange. The start of transcription and stop codon position are indicated by green and red arrowheads, respectively.

\section{Leptin and Leptin Receptor Expression in Cancer}

Single-cell RNA sequencing (scRNA-seq) has become a powerful tool to delineate the composition of different cell types or states in a given tissue on the basis of sets of differentially expressed genes [20-23]. Recently, scRNA-seq of normal tissue led to the discovery of specific biomarkers in multiple cell types that might contribute to cancer development [24]. A new cell-type atlas with publicly available genome-wide expression scRNA-seq data of 192 individual cell-type clusters from 13 different human tissues was launched in November 2020 (The Human Protein Atlas, https: / www.proteinatlas.org/, accessed on January 2021) [25]. The leptin receptor expression in the four normal tissues with the highest leptin receptor levels, namely, the skin, lung, liver, and heart, is shown at the single-cell scale (Figure 2). Relatively high leptin receptor expression was detected in fibroblasts, endothelial cells, and macrophages in skin tissue. Hepatocytes, Ito cells, endothelial cells and cholangiocytes in the liver all showed leptin receptor expression. In addition, leptin receptor expression was specifically detected in alveolar type 2 cells and endothelial cells compared with other lung cell types. In the heart, leptin receptor expression was found in endothelial cells, mixed immune cells, smooth muscle cells, and fibroblasts, but not in cardiomyocytes. These observations further suggest potential sites of leptin-mediated signaling that may play roles in tumorigenesis. 

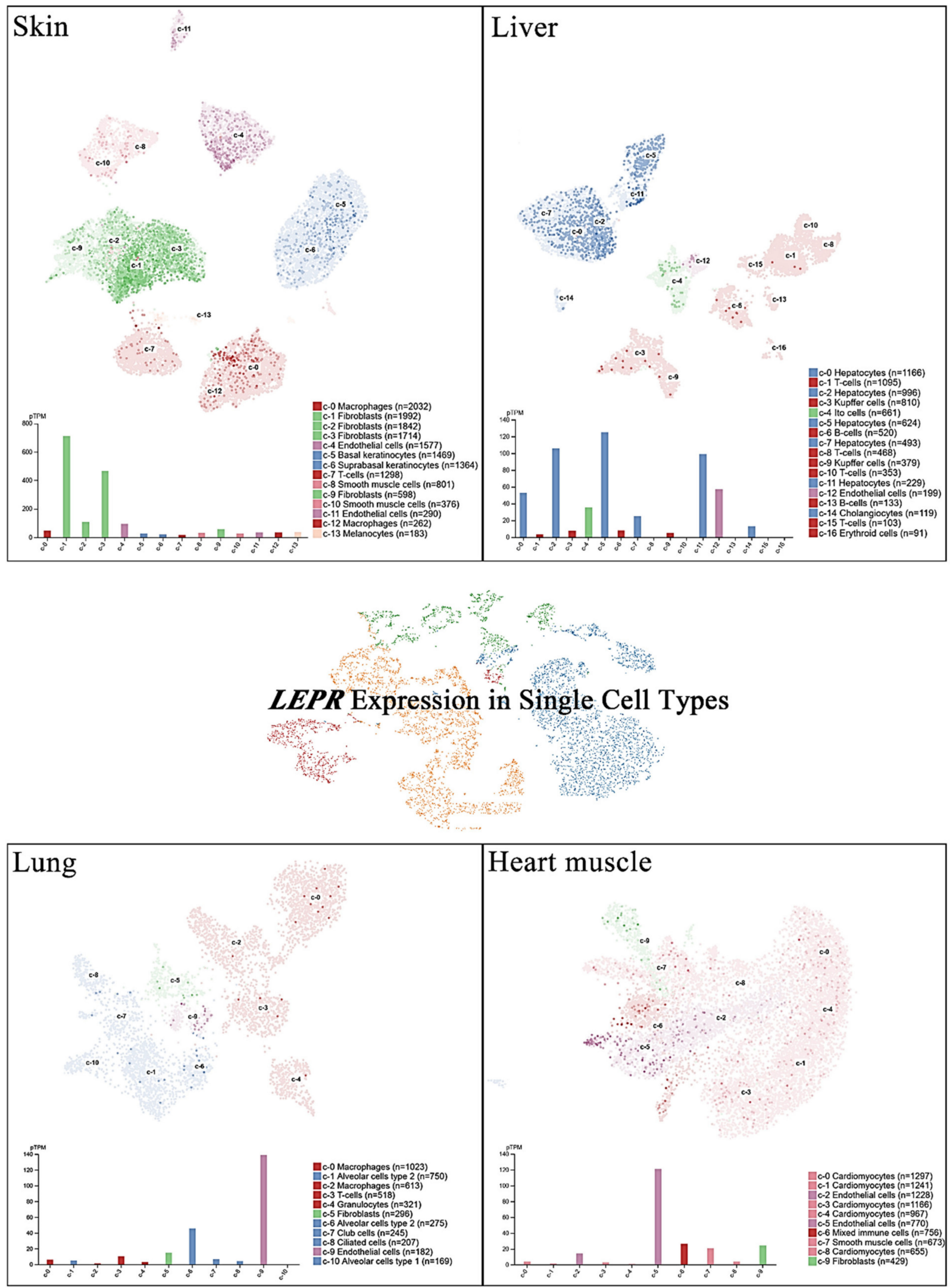

Figure 2. LEPR expression in single cells of different types. The LEPR expression level was analyzed by single-cell RNA sequencing (scRNA-seq) in various human tissues. The RNA expression levels in the cell type clusters identified in each tissue were visualized by a UMAP plot of single cells (top) and in a bar chart (bottom). The read counts were normalized to transcripts per million protein-coding genes (pTPM) for each cluster. 
Cancer cells and the tumor microenvironment expressing leptin and leptin receptors suggest that the potential leptin autocrine/paracrine signaling loop could affect tumor progression. A total of 32 blood samples from colorectal cancer patients and 25 healthy subjects were analyzed for serum levels of leptin. Leptin was significantly higher in patients than in controls $(p<0.05)$ [26]. An immunohistochemical analysis of bone metastatic tissue of breast cancer further showed that the leptin receptor was prevalently expressed in the cytosol and the nuclei of metastatic cells, whereas leptin was detected in both metastatic cells and stromal cells [27]. A cohort of gastric cancer enrolling 117 newly diagnosed and untreated patients was studied. The results indicated that LEPR methylation levels were significantly lower in tumor samples than in adjacent $(5 \mathrm{~cm}$ away) nontumor samples, suggesting the potentially high expression level of leptin receptor in gastric cancer [28]. An immunohistochemistry study using a tissue microarray of bladder cancer showed that strong leptin expression tended to be present more often in tumors than in benign tissues [29]. Higher RNA levels of both leptin and leptin receptors were found in prostate cancer patients than in healthy controls in a study including 176 men [30]. Leptin levels in patients with endometrial cancer were significantly higher than those in the control group [31].

Relative leptin and leptin receptor expression data from different types of cancers were retrieved from a public database (https:/ / ist.medisapiens.com/, accessed on January 2021) (Figure 3). The relative leptin expression level is high in head and neck cancer, peritoneal cancer, pancreatic cancer, cervical cancer, and breast cancer. In addition, leptin receptor expression is relatively high in liver cancer, indicating the potential pathological roles of this axis in cancers.
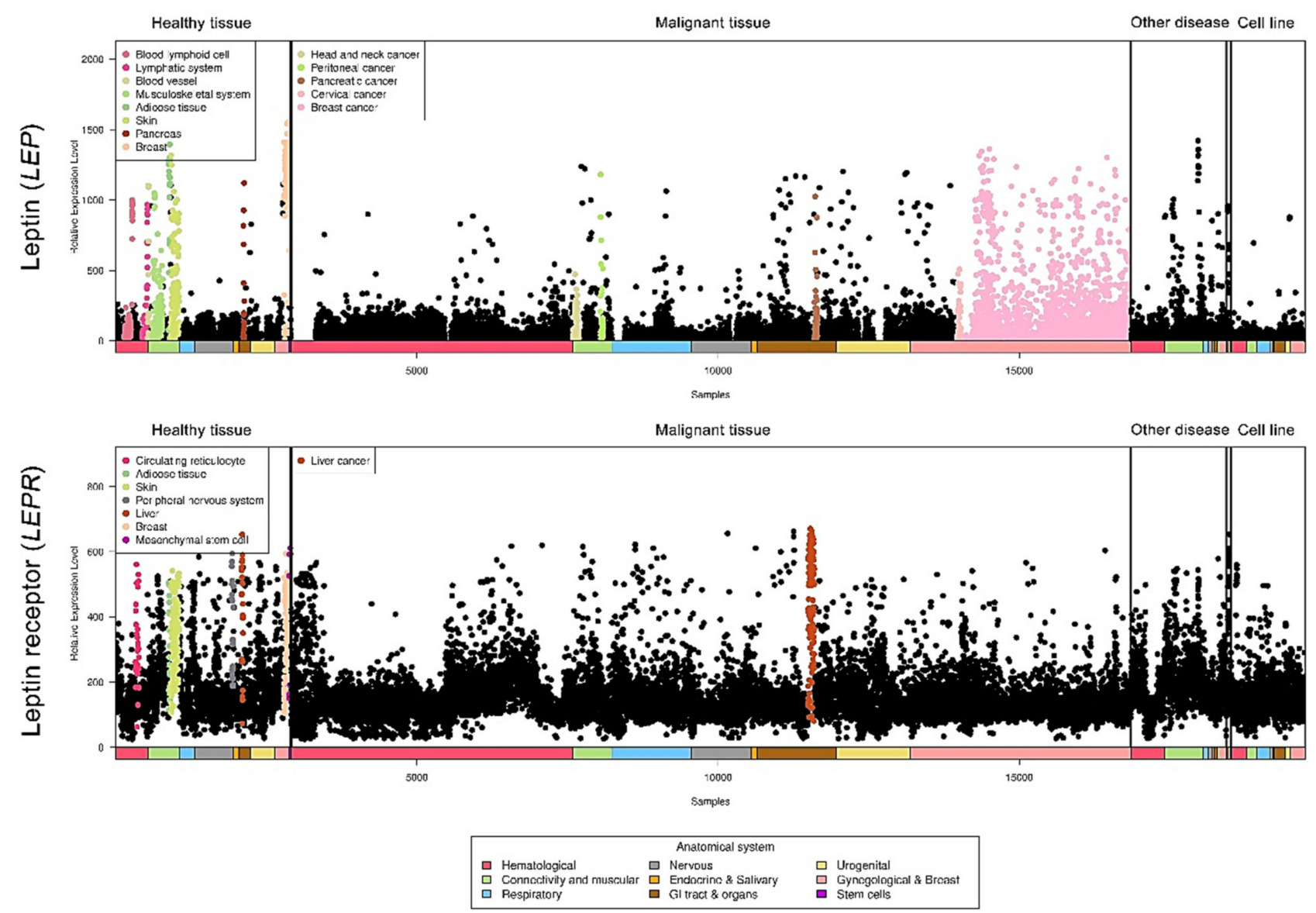

Figure 3. LEP and LEPR expression in a pancancer panel. In a pancancer dataset, LEP and LEPR expression levels were presented separately in various cancer types. The colored dots represent individual patients with higher expression of the indicated molecule among all cancer types. The raw data were retrieved from the online IST database. 


\section{LEP Somatic Mutations and Cancer}

Genetic variants of the LEP gene in cancer patients have been reported in several studies. In a case-control study with 380 gastric cancer patients and 465 normal controls, the LEP G19A polymorphism was statistically correlated with a decreased risk of cancer susceptibility [32]. Similar results were published exploring this association in a bladder cancer cohort enrolling 355 cancer cases and 435 controls (all Chinese Han). The LEP G19A polymorphism was reported to be significantly associated with lower cancer risk, smaller tumor size, less node metastasis, and less distant metastasis [33]. In a colorectal cancer cohort of 1003 cases and 1303 matched controls, LEPR rs6588147, rs1137101, and $L E P$ rs2167270 polymorphisms were found to be associated with a decrease in cancer risk, whereas LEPR rs1137100 was associated with cancer susceptibility [34]. In addition, a comprehensive encyclopedia of somatic mutation calls in cancer patients has been published by TCGA [35]. LEP mutation signatures in several cancer types are shown (Table 1).

Table 1. $L E P$ and $L E P R$ mutations in 5 major types of cancer.

\begin{tabular}{|c|c|c|c|c|c|c|c|c|}
\hline \multirow[b]{2}{*}{$L E P$} & \multicolumn{3}{|c|}{ Lung } & \multirow{2}{*}{$\begin{array}{c}\text { Liver } \\
\mathrm{t} 48 \mathrm{~m} \\
\mathrm{w} 121 \mathrm{r} \\
1161 \mathrm{q}\end{array}$} & \multicolumn{2}{|c|}{ Colon } & \multirow{2}{*}{$\begin{array}{c}\text { Glioblastoma } \\
\text { c7c }\end{array}$} & \multirow{2}{*}{$\begin{array}{c}\text { Ovarian } \\
\text { v134cfs*38 }\end{array}$} \\
\hline & $\begin{array}{l}\text { p14p } \\
\text { m89i } \\
\text { h1091 }\end{array}$ & $\begin{array}{l}\text { p23p } \\
11011 \\
\text { v134a }\end{array}$ & $\begin{array}{l}\mathrm{t} 37 \mathrm{t} \\
\mathrm{e} 102 \mathrm{~g} \\
\mathrm{~g} 166 \mathrm{v}\end{array}$ & & g8r & p231 & & \\
\hline$L E P R$ & $\begin{array}{c}\text { a21s } \\
44 \mathrm{n} \\
\text { e65d } \\
\text { s146* } \\
\text { h185y } \\
\text { i281f } \\
\text { s320i } \\
\text { t342a } \\
\text { s385t } \\
\text { i432i } \\
\text { c498y } \\
\text { e565q } \\
\text { y630f } \\
\text { g651r } \\
\text { c687g } \\
\text { w758* } \\
\text { q837k } \\
\text { k891k } \\
\text { s952c } \\
11020 \mathrm{~m} \\
\text { e1070* } \\
\text { k1086r } \\
111161\end{array}$ & $\begin{array}{c}124 \mathrm{f} \\
\text { a51d } \\
\text { r92r } \\
\text { y155f } \\
\text { v229v } \\
\text { a284a } \\
\text { t330k } \\
\text { g345w } \\
\text { n395qfs*4 } \\
\text { t451a } \\
\text { r514s } \\
\text { v600f } \\
\text { m640v } \\
\text { q677h } \\
\text { g696e } \\
\text { v792l } \\
1860 i \\
\text { a904t } \\
\text { q958* } \\
\text { s1027r } \\
\text { g1081v } \\
\text { e1089* } \\
\text { g1131v }\end{array}$ & $\begin{array}{l}\text { p30t } \\
\text { y64f } \\
\text { i123i } \\
\text { q182q } \\
\text { p264s } \\
\text { s303s } \\
\text { p338s } \\
\text { g345v } \\
\text { e424* } \\
1464 m \\
\text { d523y } \\
\text { d602y } \\
\text { k1135* } \\
\text { s686f } \\
1715 p \\
\text { e805* } \\
\text { w883r } \\
1942 \mathrm{v} \\
\text { e971d } \\
110611 \\
\text { s1084* } \\
\text { r1114k }\end{array}$ & $\begin{array}{l}\text { t685s } \\
\text { k994k } \\
\text { f1104y }\end{array}$ & $\begin{array}{c}\text { x14_splice } \\
\text { g179afs*35 } \\
\text { s256y } \\
\text { x429_splice } \\
\text { v430i } \\
\text { w558* } \\
\text { s595s } \\
\text { v606v } \\
\text { i8141 } \\
\text { v846v } \\
\text { s927s } \\
\text { k1074t }\end{array}$ & $\begin{array}{c}\text { d124y } \\
\text { v198a } \\
\text { s303s } \\
11094 f \\
\text { s541p } \\
\text { r573h } \\
1598 p \\
\text { r612c } \\
\text { i845t } \\
\text { d921y } \\
\text { q1034h } \\
\text { s1090r }\end{array}$ & $\begin{array}{c}\text { a458v } \\
\text { x799_splice }\end{array}$ & $\begin{array}{c}\text { s601 } \\
\text { t85i } \\
\text { q463h } \\
\text { s905* } \\
\text { s1090i }\end{array}$ \\
\hline
\end{tabular}

Missense and frameshifts mutation (fs) were labelled in red color. Silent, nonsense $\left(^{*}\right)$ and splice site (_splice) mutations were labelled in blue color.

\subsection{Leptin and Ovarian Cancer}

The influence of leptin on chemoresistance in epithelial ovarian cancer has been studied. Treatment with exogenous leptin decreased paclitaxel/docetaxel-induced G2/M phase cell cycle arrest in ovarian cancer cells [36]. However, experimental results from another research group showed that serum levels of leptin were not correlated with the response to paclitaxel/carboplatin therapy in ovarian cancer patients [37]. Leptin-induced ovarian cancer cell invasion via overexpression of MMP7, MMP9, and UPA was reported, and the involvement of the estrogen-independent role of ER $\alpha$ in regulating the phenotype was indicated [38]. In addition, leptin was found to elicit matrix metalloproteinase 7 expression, leading to increased ovarian cancer cell invasion via ERK and JNK pathway activation [39]. Furthermore, the RhoA-ROCK signaling axis was verified to mediate leptin-promoted uPA 
expression to promote cell invasion in ovarian cancer cells [40]. Leptin has also been shown to regulate cancer cell proliferation. The biological effect of leptin on inducing ovarian cancer cell growth was mediated by an increase in cyclin D1 and Mcl-1 expression after the activation of the PI3K/Akt and MEK/ERK1/2 signaling axes [41]. Treatment with recombinant leptin was found to contribute to ovarian cancer cell migration, invasion, peritoneal metastasis and epithelial-mesenchymal transition (EMT), and the malignant phenotypes were caused by activation of the PI3K/Akt/mTOR signaling pathway [42]. The overexpression of histone deacetylases (HDACs) was known to elicit carcinogenesis, and leptin receptor antagonists, SHLA and Lan2, were shown to eliminate the effect induced by leptin in ovarian cancer [43].

\subsection{Leptin and Brain Tumor}

Leptin and its receptor were reported to be highly expressed in brain tumors, and the patients with the tissues displaying those biomarkers associated with the degree of malignancy [44]. The roles of the leptin-leptin receptor signaling axis in brain tumor progression were evaluated. The biological interaction of leptin with Notch signaling pathways was found to be required for glioblastoma multiforme (GBM) development and progression. The activation of leptin downstream effectors induced growth and motility in GBM cells, and the induced effects on GBM cancer cells were inhibited by the selective leptin antagonist as well as by the specific inhibitor of Notch signaling, suggesting that leptin/Notch crosstalk may be a potential novel target for GBM therapeutics [45]. Leptin treatment alone and cotreatment with secreted phospholipase A2-IIA (sPLA2-IIA) led to the phosphorylation activation of the Src/ERK/Akt/mTOR/p70S6K/rS6 pathway, thereby inducing cell proliferation in the human astrocytoma cell line 1321N1 [46]. In addition, leptin signaling is linked to angiogenesis in glioblastoma, and the correlation of leptin receptors with vasculogenic mimicry (VM) has been identified [47]. The observation of the leptin signaling axis in inducing angiogenesis was then reported by another group, which further showed the reverse effect of Aca1 (leptin receptor antagonist) on endothelial cell tube formation activity [48]. Moreover, ectopic leptin receptor overexpression resulted in temozolomide (TMZ) resistance in glioblastoma, and the involvement of stem/progenitor cell properties and STAT3 signaling was indicated [49].

\subsection{Leptin and Breast Cancer}

The reciprocal interaction of the adipose microenvironment and breast cancer tissue is a critical factor in promoting cancer cell migration [50]. Experimental results showed that adipose cells led to a decrease in the viability of myoepithelial cells (MECs), which are known as tumor suppressor cells that block the transition from ductal carcinoma in situ to invasive carcinoma. Both leptin amplification and the disruption of genes involved in extracellular matrix maintenance were observed during this stage [51]. The effect of the adipokine leptin on normal mammary epithelial cells was investigated. Leptin treatment triggers EMT-like features, including migration speed, via the interdependent activity of leptin receptor and $\mathrm{Ca}^{2+}$ channel-mediated myosin light chain kinase-2 (MLC2) phosphorylation [52]. An orthotopic implantation metastasis model further revealed that plasminogen activator inhibitor-1 (PAI-1) is required for breast cancer metastasis. Mechanistically, the upregulation of PAI-1 expression was elicited by leptin-LEPR-miR-34a axis-mediated STAT3 signaling activation [53]. Leptin also elicits metabolic reprogramming in breast cancer. This function was found to be accompanied by autophagy activation and SREBP-1 induction, leading to stimulated cell proliferation [54]. A breast cancer cohort including 106 cases was studied. Higher leptin receptor expression levels were associated with an increased incidence of bone metastasis in breast cancer patients. Leptin addition also activated the SDF-1/CXCR4 axis to promote invasive behavior in the breast cancer cell lines MCF-7 and SK-BR-3 [55]. The loss of LEPR expression in breast cancer was also observed to modulate the tumor microenvironment. With LEPR loss, cancer cells exhibited a less aggressive phenotype, and macrophage recruitment was abolished; the 
phagocytic activity and cytokine production of macrophages also appeared to decrease [56]. Cotreatment with leptin and adipose tissue-derived fibroblast growth factor-2 (FGF2) was reported to induce the malignant transformation of breast epithelial MCF-10A cells, and this effect was found to be attenuated by ruxolitinib and AG490, two separate inhibitors of Jak2, which is downstream of the leptin receptor, suggesting the critical interplay of leptin, leptin receptor and Jak2 in cancer progression [57]. The inhibitory effects of globular adiponectin on leptin-promoted inflammasome activation and tumor growth were further verified in breast MCF-7 cell and xenograft models via mechanisms including HO-1 induction and ER- $\alpha$ signaling modulation [58]. In addition, tamoxifen was found to increase the expression of leptin receptor in breast cancer cell lines, leading to the decrease of drug sensitivity in inhibiting cell proliferation [59].

\subsection{Leptin and Liver Cancer}

The role of the leptin-leptin receptor axis in triggering hepatic tumor malignancy was identified. Leptin was discovered to elicit the phosphorylation activation of STAT3, ERK1/2, and Akt in liver cancer cells, thereby enhancing cell proliferation and migration ability. In particular, the adaptor protein APPL1 directly interacts with STAT3 and leptin receptors to enhance the aforementioned phenotypes in the human hepatocellular carcinoma cell line HepG2 [60]. In addition, leptin receptor was characterized to be expressed in various types of cancer, suggesting biological functions for leptin outside of appetite regulation. Overexpression of leptin receptor was significantly associated to the unfavored TNM status in hepatocellular carcinoma [61]. In another report of human hepatocellular carcinoma, leptin/leptin receptor expression was observed in both tumor and endothelial cells, in parallel to the degree of angiogenesis [62]. The underlying mechanisms of LEPR in liver cancer metastasis were addressed. LEPR could enhance proliferation, migration, and invasion and inhibit apoptosis in lymphatic metastasis of hepatocellular carcinoma by directly interacting with ANXA7 [63]. Interestingly, the leptin-derived peptide (mimetic), OB3, was able to abolish leptin-induced cell proliferation by reducing phosphoinositide 3-kinase (PI3K) activation and the expression of proinflammatory genes in hepatocellular carcinoma cells [64]. The opposite function of leptin in cell proliferation was reported in rat hepatocellular carcinoma, which occurs via a p38-MAPK-dependent signaling pathway to attenuate serum-induced H4IIE cell proliferation [65].

\subsection{Leptin and Colorectal Cancer}

Notably, a study in colon cancer demonstrated that leptin could upregulate miR-4443 to restrain TRAF4 and NCOA1 expression, leading to decreased cancer invasion [66]. In addition, leptin stimulation was found to promote the migration and invasion of cultured HCT-116 cells, tumor growth in the xenograft model and the upregulation of SIRT1. These effects were abolished by the addition of the SIRT1 inhibitor sirtinol, indicating the critical involvement of SIRT1 in obesity-associated colon carcinogenesis [67]. The critical role of leptin receptor expression in the proliferation of colorectal carcinoma has also been evaluated in the clinic. The absence of leptin receptor expression was found to be associated with a low tumor proliferation index in $94.1 \%$ of cases [68]. In a cohort study of 75 colorectal carcinoma patients, elevated LEPR expression was accompanied by the observation of neoangiogenesis and an increase in metastatic potential [69]. The carcinogen-induced aberrant crypt foci (ACF) was reduced in the intestinal epithelium-specific leptin receptor conditional knockout mice accompanied by the activation of STAT3 signaling, indicating its impact on tumorigenesis [70]. Interestingly, the unique ability of leptin to target the leptin receptor was exploited to enhance drug delivery in colon cancer. PEGylated liposomal doxorubicin decorated with a leptin-derived peptide (Lp31) showed improved uptake by and cytotoxicity against $\mathrm{C} 26$ cells. The results of animal experiments revealed the suppression of tumor growth, consistent with the increased doxorubicin concentration in tumor tissue [71]. A similar outcome was published by another group using leptin- 
derived peptide (LP16, 91-110 of leptin) to reduce tumor growth in a C26 colon carcinoma tumor-bearing mouse model [72].

\subsection{Leptin and Lung Cancer}

The expressions of leptin and leptin receptor were significantly higher in non-smallcell lung cancer (NSCLC) tissues than in normal lung tissues [73]. In addition, a cohort of 71 patients with early-stage NSCLC was studied. The mean serum leptin level was found to be significantly higher in patients with adenocarcinoma than in those with the squamous cell subtype, suggesting that measuring serum leptin could be a noninvasive method for pathological diagnosis [74]. In clinical data, the correlation of leptin and leptin receptor expression with bone metastasis was detected in pulmonary adenocarcinoma patients [75]. Leptin was able to induce EMT in the lung cancer cell line A549, thereby promoting cell migration, invasion, and tumorigenesis. The study also provided evidence that leptin-induced malignancies were driven through the activation of the ERK signaling axis [76]. In a study of brain metastasis of lung adenocarcinoma, activation of leptin signaling was highlighted in the context of the lnc-REG3G-3-1 $1^{\text {high }} / \mathrm{miR}-215-3 \mathrm{p}^{\text {low }}$ axis [77]. The assessment of leptin drug resistance showed that bone marrow-derived mesenchymal stem cells could release leptin to induce erlotinib resistance in lung adenocarcinoma cells by activating IGF-1R signaling in a hypoxic environment, suggesting a predictive role of leptin expression for therapeutic response [78]. Similar observations showed that leptin overexpression decreased the cisplatin-mediated ER stress unfolded protein response pathways PERK and ATF6 to promote lung adenocarcinoma A549 cell proliferation [79]. In addition, a carcinogenic role of leptin in the tumor microenvironment was discovered. Leptin secretion from cancer-associated fibroblasts (CAFs) could trigger the proliferation and migration of NSCLC cells through the activation of the PI3K-AKT and MAPK-ERK signaling axes in a paracrine manner [80].

\subsection{Leptin and Pancreatic Cancer}

Oncogenic hypoxia inducible factor (HIF)-1 $\alpha$ was identified to bind directly to hypoxiaresponsive elements (HREs) located in the LEPR gene promoter (-828/-832), thereby activating downstream transcriptional events in pancreatic cancer cells, suggesting the potential significance of the leptin receptor-mediated axis during hypoxia [81]. In a study of pancreatic cancer, the results demonstrated that exogeneous leptin could enhance cell proliferation, glucose uptake and lactate production in a dose-dependent manner, and that this was accompanied by elevated expression of the glycolytic enzymes hexokinase II and glucose transporter 1, suggesting the potential involvement of glucose metabolism in pancreatic cancer progression [82]. In addition, simultaneously high leptin receptor and MMP13 production exhibited a positive correlation with TNM status in pancreatic cancer patients. Leptin-induced cancer cell migration, invasion and metastasis were also observed in a pancreatic orthotopic model [83]. Another research group further indicated that leptin could promote cancer progression and increase ABCB1 protein synthesis in pancreatic cancer [84]. Emerging studies have referred to the participation of the leptin signaling axis in drug resistance. Leptin levels in serum were found to be higher in patients with pancreatic adenocarcinoma and correlated with resistance to gemcitabine chemotherapy [85]. Furthermore, leptin was reported to elicit chemoresistance in pancreatic ductal adenocarcinoma, and the results indicated that gemcitabine resistance develops via miR-342-3p upregulation-dependent inhibition of KLF6 signaling in cancer cells [86]. Leptin also decreased 5-fluorouracil (5-FU) cytotoxicity and promoted cell proliferation, colony formation ability, and stem cell pluripotency. The expression of EMT markers, drug efflux proteins (ABCC5, ABCC11) and Notch appeared to be upregulated [87]. The role of leptin receptor in pancreatic cancer was also reported. Reduction of leptin receptor by shRNA knockdown was observed to partially abrogate tumor growth in obese mice of orthotopic murine pancreatic cancer model [88]. 


\subsection{Leptin and Other Types of Cancer}

In prostate cancer, an increase in DU145 cell proliferation and invasion and a decrease in cell apoptosis due to ERK1/2 signaling activation after leptin treatment were reported [89]. The effect of leptin on prostate cancer progression was assessed in DU-145 and PC3 cell lines. Leptin treatment appeared to promote cancer cell migration and EMT transition by activating the STAT3 pathway [90]. Findings in human gallbladder cancer suggested the requirement of leptin-leptin receptor signaling axis activation in cancer progression because leptin increased cell proliferation via the leptin receptor [91]. In myeloma, bortezomib treatment-induced cytotoxicity was attenuated by leptin, accompanied by the upregulation of cyclin D1 and Bcl-2 and downregulation of caspase 3 [92]. In chondrosarcoma, there is significant evidence that leptin can induce VEGF-C expression and its secretion, contributing to the lymphangiogenesis of human lymphatic endothelial cells by repressing miR-27b [93]. Leptin-dependent regulation of tube formation in endothelial progenitor cells was shown in a chondrosarcoma cell study. MAPK signaling was activated to induce AP-1 binding to the VEGF-A promoter and initiate transactivation upon stimulation of the leptin-leptin receptor signaling axis in cancer cells [94]. In addition, a correlation analysis further indicated the positive association of leptin and leptin receptor levels with lymph node metastasis in endometrial cancer patients [95]. A study aiming to counteract leptin-mediated cancer metastasis was reported. Adiponectin was found to attenuate leptin-elicited SPEC-2 endometrial cancer metastasis by inhibiting the JAK/STAT3 pathway via AMPK activation [96]. In a study of squamous cell carcinoma of the skin, leptin receptor expression as evaluated by immunostaining was significantly correlated with poor differentiation, proliferation index and tumor histologic grade [97]. Another clinical study revealed that cutaneous melanoma patients with higher leptin levels in serum samples also had a high risk of sentinel lymph node metastasis [98]. In addition, elevation of VEGF-A expression by leptin was reported in melanoma [99]. The demonstrations of main biological effects (Table 2) and signaling axes (Figure 4) induced by leptin/leptin receptor in different cancer types were shown.

Table 2. Main effects of leptin/leptin receptor in different cancer types.

\begin{tabular}{|c|c|c|c|c|c|}
\hline & Proliferation & Angiogenesis & Metastasis & Apoptosis & Drug Resistance \\
\hline Ovarian Cancer & $\uparrow:[41]$ & & $\uparrow:[38-40,42]$ & & $\uparrow:$ (paclitaxel/docetaxel) [36] \\
\hline Brain Tumor & $\uparrow:[45,46]$ & $\uparrow:[47,48]$ & $\uparrow:[45]$ & & $\uparrow:$ (temozolomide) [49] \\
\hline Breast Cancer & $\uparrow:[54,58]$ & & $\uparrow:[53,55]$ & & \\
\hline Liver Cancer & $\begin{array}{c}\uparrow:[60,63] \\
\downarrow:[65] \text { (rat) }\end{array}$ & & $\uparrow:[60,63]$ & $\downarrow:[63]$ & \\
\hline Colorectal Cancer & $\uparrow:[67,70]$ & & $\begin{array}{l}\uparrow:[67] \\
\downarrow:[66]\end{array}$ & & \\
\hline Lung Cancer & $\uparrow:[79,80]$ & & $\uparrow:[76,77,80]$ & & $\uparrow:$ (erlotinib) [78], (cisplatin) [79] \\
\hline Pancreatic Cancer & $\uparrow:[82,87,88]$ & & $\uparrow:[83]$ & & $\uparrow:$ (gemcitabine) [86], (5-FU) [87] \\
\hline Prostate Cancer & $\uparrow:$ [89] & & $\uparrow:[89,90]$ & $\downarrow:[89]$ & \\
\hline Gallbladder cancer & $\uparrow:[91]$ & & & & \\
\hline Myeloma & & & & & $\uparrow:$ (bortezomib) [92] \\
\hline Chondrosarcoma & & $\uparrow:[93,94]$ & & & \\
\hline
\end{tabular}




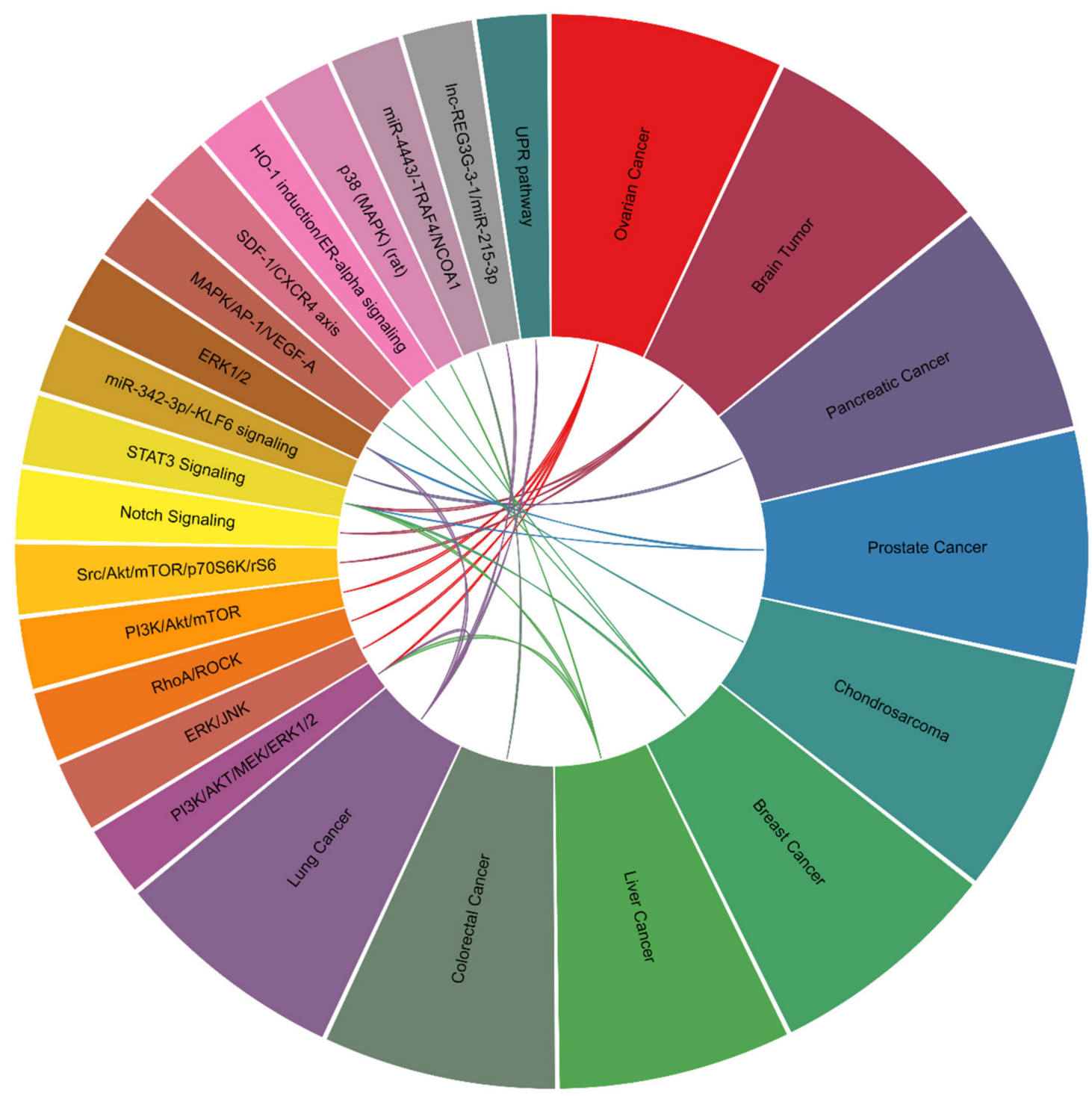

Figure 4. Signaling axes modulated by leptin/leptin receptor.

\section{Correlation of Leptin and Leptin Receptor Levels with Clinical Outcomes in Cancer}

The clinical association of leptin and leptin receptor expression with cancer patient outcomes has been explored, and the positive association of leptin with hepatocellular carcinoma risk was recently reported [100]. Interestingly, the specific cellular localization of leptin shows prognostic power; its nuclear expression was identified to be significantly associated with overall survival in patients with clear cell renal cell carcinomas [101]. In bladder cancer, a multivariate analysis revealed a higher risk of progression $(\mathrm{HR}=5.148,95 \% \mathrm{CI}$ $=1.190-22.273 ; p=0.028$ ) in patients with leptin-positive muscle-invasive tumors [29]. In addition, a positive association between LEPR mRNA expression and unfavorable prognosis was found in prostate cancer [90]. A similar positive correlation was also discovered between leptin/leptin receptor overexpression and distant metastasis in a cohort of 176 prostate cancer patients [30]. The expression levels of leptin and its receptor were both found to be associated with unfavorable prognosis in patients with endometrial cancer (3-year survival rate) [95]. A cohort study enrolling ovarian cancer patients indicated a significant correlation of leptin and leptin receptor coexpression with shorter survival time [102]. In addition, serum leptin and leptin receptor RNA expression showed a positive association with cancer recurrence and mortality in triple-negative breast cancer [103]. Leptin levels also exhibited a positive correlation with poor prognosis in ovarian cancer [42], 
and high leptin levels were found in multiple myeloma patients and to correlate with clinical stage [92]. The leptin receptor also displays prognostic significance in the clinic. Patients with glioblastoma showing poor prognosis have high leptin receptor levels [47]. In upper tract urothelial carcinomas, leptin receptor expression was associated with unfavorable prognosis for recurrence-free survival $(p=0.09)$ and cancer-specific survival $(p=0.01)$ by log-rank test. Cox regression analysis further characterized leptin receptor expression as an independent biomarker predicting poor survival [104]. In contrast, results illustrating the negative correlation of leptin or leptin receptors with cancer progression have also been reported. Immunohistochemical staining showed that cytoplasmic leptin was less frequently observed in breast cancers with unfavorable prognosis [105]. In nonmetastatic renal cell carcinoma, a relatively high disease recurrence rate and low recurrence-free survival rate were associated with high CpG methylation in the LEPR gene promoter region [106]. LEP RNA expression profiles investigated by RNA-seq and microarray approaches have been released together with clinical patient follow-up data from public databases, including The Human Protein Atlas/The Pathology Atlas [25,107-110] and the Kaplan-Meier plotter database [111], which illustrate the prognostic value of LEP in specific cancer types (Table 3). $L E P$ was an unfavorable prognostic marker in cohorts of glioma, lung cancer, colorectal cancer, renal cancer, ovarian cancer, and melanoma, while in patients with thyroid cancer, pancreatic cancer, and breast cancer, high $L E P$ levels were associated with favorable outcomes. LEPR is a well-known receptor that triggers leptin-mediated biological effects. The correlation with cancer patient survival outcomes is also listed for comparison in Table 4. High LEPR expression is associated with poor outcomes in patients with thyroid cancer, breast cancer, cervical cancer, ovarian cancer, and gastric cancer. The clinical discrepancy observed among different research groups might result from the differences including the human races, case numbers enrolled in each cohort, endpoint setting, quality of care in hospitals, detection platforms (microarray vs next generation sequencing), random errors, and the involvement of complicated interaction networks contributing to the different outcomes in specific cancer types. 
Table 3. Correlation of $L E P$ with cancer patient survival.

\begin{tabular}{|c|c|c|c|c|c|c|c|c|}
\hline Symbol & Cancer Type & Prognosis & Endpoint & $p$-Value & Case & Dataset & Method & Probe ID \\
\hline$L E P$ & Glioma & Poor & Overall survival & 0.01 & 153 & TCGA & RNA-seq & \\
\hline LEP & Thyroid Cancer & Good & Overall survival & 0.022 & 501 & TCGA & RNA-seq & \\
\hline LEP & Lung Cancer & Poor & Overall survival & 0.0066 & 994 & TCGA & RNA-seq & \\
\hline LEP & Colorectal Cancer & Poor & Overall survival & $<0.001$ & 597 & TCGA & RNA-seq & \\
\hline LEP & Head and Neck Cancer & - & Overall survival & N.S. & 499 & TCGA & RNA-seq & \\
\hline LEP & Stomach Cancer & - & Overall survival & N.S. & 354 & TCGA & RNA-seq & \\
\hline LEP & Liver Cancer & $\mathrm{N} / \mathrm{A}$ & Overall survival & $\mathrm{N} / \mathrm{A}$ & 365 & TCGA & RNA-seq & \\
\hline LEP & Pancreatic Cancer & Good & Overall survival & 0.025 & 176 & TCGA & RNA-seq & \\
\hline LEP & Renal Cancer & Poor & Overall survival & 0.001 & 877 & TCGA & RNA-seq & \\
\hline LEP & Urothelial Cancer & - & Overall survival & N.S. & 406 & TCGA & RNA-seq & \\
\hline LEP & Prostate Cancer & - & Overall survival & N.S. & 494 & TCGA & RNA-seq & \\
\hline LEP & Testis Cancer & - & Overall survival & N.S. & 134 & TCGA & RNA-seq & \\
\hline LEP & Breast cancer & Good & Overall survival & 0.0082 & 1075 & TCGA & RNA-seq & \\
\hline LEP & Cervical Cancer & - & Overall survival & N.S. & 291 & TCGA & RNA-seq & \\
\hline LEP & Ovarian Cancer & Poor & Overall survival & 0.014 & 373 & TCGA & RNA-seq & \\
\hline LEP & Melanoma & Poor & Overall survival & 0.02 & 102 & TCGA & RNA-seq & \\
\hline LEP & Breast cancer & Good & Overall survival & 0.037 & 1402 & $\begin{array}{c}\text { E-MTAB-365, E-TABM-43, GSE: } 11,121,12,093, \\
12,276,1456,16,391,16,446,16,716,17,705,17,907, \\
\text { 18,728, 19,615, 20,194, 20,271, 2034, 20,685, 20,711, } \\
21,653,2603,26,971,2990,31,448,31,519,32,646, \\
3494,37,946,41,998,42,568,45,255,4611,5327 \\
6532,7390,9195\end{array}$ & Array & 207092_at \\
\hline LEP & Ovarian cancer & - & Progression-free survival & N.S. & 1435 & $\begin{array}{c}\text { GSE: } 14,764,15,622,18,520,19,829,23,554,26,193, \\
26,712,27,651,30,161,3149,51,373,63,885,65,986, \\
9891, \text { TCGA }(\mathrm{N}=565)\end{array}$ & $\begin{array}{c}\text { Array } \\
\text { RNA-seq }\end{array}$ & 207092_at \\
\hline \multirow[t]{2}{*}{ LEP } & Lung cancer & - & Post-progression survival & N.S. & 344 & CAARRAY, GSE: $14,814,19,188,29,013,30,219$, & Array & 207092_at \\
\hline & & & & & & $\begin{array}{c}31,210,3141,31,908,37,745,43,580,4573,50,081 \\
8894, \text { TCGA }(\mathrm{N}=133)\end{array}$ & RNA-seq & \\
\hline LEP & Gastric cancer & - & Overall survival & N.S. & 875 & GSE: $14,210,15,459,22,377,29,272,51,105,62,254$ & Array & 207092_at \\
\hline
\end{tabular}


Table 4. Correlation of LEPR with cancer patient survival.

\begin{tabular}{|c|c|c|c|c|c|c|c|c|}
\hline Symbol & Cancer Type & Prognosis & Endpoint & $p$-Value & Case & Dataset & Method & Probe ID \\
\hline$L E P R$ & Glioma & - & Overall survival & N.S. & 153 & TCGA & RNA-seq & \\
\hline$L E P R$ & Thyroid Cancer & Poor & Overall survival & 0.035 & 501 & TCGA & RNA-seq & \\
\hline$L E P R$ & Lung Cancer & - & Overall survival & N.S. & 994 & TCGA & RNA-seq & \\
\hline$L E P R$ & Colorectal Cancer & - & Overall survival & N.S. & 597 & TCGA & RNA-seq & \\
\hline$L E P R$ & Head and Neck Cancer & - & Overall survival & N.S. & 499 & TCGA & RNA-seq & \\
\hline$L E P R$ & Stomach Cancer & - & Overall survival & N.S. & 354 & TCGA & RNA-seq & \\
\hline$L E P R$ & Liver Cancer & - & Overall survival & N.S. & 365 & TCGA & RNA-seq & \\
\hline$L E P R$ & Pancreatic Cancer & - & Overall survival & N.S. & 176 & TCGA & RNA-seq & \\
\hline$L E P R$ & Renal Cancer & - & Overall survival & N.S. & 877 & TCGA & RNA-seq & \\
\hline LEPR & Urothelial Cancer & - & Overall survival & N.S. & 406 & TCGA & RNA-seq & \\
\hline$L E P R$ & Prostate Cancer & - & Overall survival & N.S. & 494 & TCGA & RNA-seq & \\
\hline LEPR & Testis Cancer & - & Overall survival & N.S. & 134 & TCGA & RNA-seq & \\
\hline LEPR & Breast cancer & Poor & Overall survival & 0.016 & 1075 & TCGA & RNA-seq & \\
\hline LEPR & Cervical Cancer & Poor & Overall survival & 0.0011 & 291 & TCGA & RNA-seq & \\
\hline LEPR & Ovarian Cancer & Poor & Overall survival & 0.0066 & 373 & TCGA & RNA-seq & \\
\hline LEPR & Melanoma & - & Overall survival & N.S. & 102 & TCGA & RNA-seq & \\
\hline$L E P R$ & Breast cancer & - & Overall survival & N.S. & 1402 & $\begin{array}{c}\text { E-MTAB-365, E-TABM-43, GSE: } 11,121,12,093, \\
12,276,1456,16,391,16,446,16,716,17,705,17,907, \\
18,728,19,615,20,194,20,271,2034,20,685,20,711, \\
21,653,2603,26,971,2990,31,448,31,519,32,646, \\
3494,37,946,41,998,42,568,45,255,4611,5327, \\
6532,7390,9195\end{array}$ & Array & 207255_at \\
\hline$L E P R$ & Ovarian cancer & Poor & Progression-free survival & 0.036 & 1435 & $\begin{array}{c}\text { GSE: } 14,764,15,622,18,520,19,829,23,554,26,193, \\
26,712,27,651,30,161,3149,51,373,63,885,65,986, \\
9891, \text { TCGA }(\mathrm{N}=565)\end{array}$ & $\begin{array}{c}\text { Array } \\
\text { RNA-seq }\end{array}$ & 207255_at \\
\hline$L E P R$ & Lung cancer & - & Overall survival & N.S. & 1925 & $\begin{array}{c}\text { CAARRAY, GSE: } 14,814,19,188,29,013,30,219, \\
\text { 31,210, 3141, 31,908, 37,745, 43,580, 4573, 50,081, } \\
\text { 8894, TCGA }(\mathrm{N}=133)\end{array}$ & RNA-seq & 207255_at \\
\hline$L E P R$ & Gastric cancer & Poor & Overall survival & $<0.001$ & 875 & GSE: $14,210,15,459,22,377,29,272,51,105,62,254$ & Array & 207255_at \\
\hline
\end{tabular}

Survival data was collected from The Human Protein Atlas, Kaplan-Meier plotter databases. N.S.: no significance. N/A: not applicable. 


\section{Summary and Perspectives}

According to published findings and in silico analyses of clinical cancer databases, the expression of leptin and leptin receptors is found in many types of cancer. The signaling axis also plays a critical role in regulating several key processes in cancer progression, including cell proliferation, metastasis, angiogenesis, and drug resistance. We demonstrated the relative expression levels of leptin and leptin receptors in a pancancer panel. The differential RNA expression in specific cancer types suggests a potential alteration of upstream transcriptional activity and RNA stability that might be of value for further investigations in tumorigenesis and cancer progression. In the clinic, the discrepancy in observations among different research groups might result from the variations including the human races, case numbers enrolled in each cohorts, detection platforms and the involvement of complicated interaction networks contributing to the different outcomes in specific cancer types. We also listed controversial functional roles of leptin in liver cancer proliferation (Table 2), which might be due to the differences between humans and rats. In addition to the variation in the experimental procedures, it is possible that the leptin-mediated stimulatory or inhibitory effects are partly altered by other receptors which are still unknown in cancers, which might cause the discrepancies in leptin's functional roles. Notably, the relative expression levels of leptin and leptin receptors were not uniformly distributed across the pancancer cohort. Head and neck cancer, peritoneal cancer, pancreatic cancer, cervical cancer, and breast cancer all expressed relatively high leptin but not leptin receptor, which suggests that the potential pathological involvement of other novel leptin receptors in tumors are required to be further explored and identified.

Funding: This study was funded by Chang Gung Memorial Hospital, Linkou, (CMRPG3K0871), Taiwan and the Ministry of Science and Technology (1072314-B-182A-158-MY3), Taiwan to TsungChieh, Lin.

Acknowledgments: We are grateful for help obtained from the Genomic Medicine Core Laboratory, Chang Gung Memorial Hospital, Linkou, Taiwan.

Conflicts of Interest: The authors declare no conflict of interest.

\section{References}

1. Tartaglia, L.A.; Dembski, M.; Weng, X.; Deng, N.; Culpepper, J.; Devos, R.; Richards, G.J.; Campfield, L.A.; Clark, F.T.; Deeds, J.; et al. Identification and expression cloning of a leptin receptor, OB-R. Cell 1995, 83, 1263-1271. [CrossRef]

2. Halaas, J.L.; Gajiwala, K.S.; Maffei, M.; Cohen, S.L.; Chait, B.T.; Rabinowitz, D.; Lallone, R.L.; Burley, S.K.; Friedman, J.M. Weight-reducing effects of the plasma protein encoded by the obese gene. Science 1995, 269, 543-546. [CrossRef]

3. Charchour, R.; Dufour-Rainfray, D.; Morineau, G.; Vatier, C.; Fellahi, S.; Vigouroux, C.; Genoux, A.; Capeau, J.; Lacorte, J.M.; Collet, C.; et al. Mutltifaceted biological roles of leptin. Ann. Biol. Clin. 2020, 78, 231-242. [CrossRef] [PubMed]

4. Garcia-Castano, A.; Madariaga, L.; de Nanclares, G.P.; Ariceta, G.; Gaztambide, S.; Castano, L. Novel mutations associated with inherited human calcium-sensing receptor disorders: A clinical genetic study. Eur. J. Endocrinol. 2019, 180, 59-70. [CrossRef] [PubMed]

5. Scheja, L.; Heeren, J. The endocrine function of adipose tissues in health and cardiometabolic disease. Nat. Rev. Endocrinol. 2019, 15, 507-524. [CrossRef] [PubMed]

6. Opatrilova, R.; Caprnda, M.; Kubatka, P.; Valentova, V.; Uramova, S.; Nosal, V.; Gaspar, L.; Zachar, L.; Mozos, I.; Petrovic, D.; et al. Adipokines in neurovascular diseases. Biomed. Pharmacother. 2018, 98, 424-432. [CrossRef]

7. Pham, D.V.; Park, P.H. Recent insights on modulation of inflammasomes by adipokines: A critical event for the pathogenesis of obesity and metabolism-associated diseases. Arch. Pharmacal. Res. 2020, 43, 997-1016. [CrossRef]

8. Schwartz, M.W.; Woods, S.C.; Porte, D., Jr.; Seeley, R.J.; Baskin, D.G. Central nervous system control of food intake. Nature 2000, 404, 661-671. [CrossRef] [PubMed]

9. Tartaglia, L.A. The leptin receptor. J. Biol. Chem. 1997, 272, 6093-6096. [CrossRef] [PubMed]

10. Lipsey, C.C.; Harbuzariu, A.; Daley-Brown, D.; Gonzalez-Perez, R.R. Oncogenic role of leptin and Notch interleukin-1 leptin crosstalk outcome in cancer. World J. Methodol. 2016, 6, 43-55. [CrossRef]

11. Allison, M.B.; Myers, M.G., Jr. 20 years of leptin: Connecting leptin signaling to biological function. J. Endocrinol. 2014, 223, T25-T35. [CrossRef] [PubMed]

12. Mullen, M.; Gonzalez-Perez, R.R. Leptin-Induced JAK/STAT Signaling and Cancer Growth. Vaccines 2016, 4, 26. [CrossRef] 
13. Howard, J.M.; Pidgeon, G.P.; Reynolds, J.V. Leptin and gastro-intestinal malignancies. Obes. Rev. Off. J. Int. Assoc. Study Obes. 2010, 11, 863-874. [CrossRef] [PubMed]

14. Garofalo, C.; Koda, M.; Cascio, S.; Sulkowska, M.; Kanczuga-Koda, L.; Golaszewska, J.; Russo, A.; Sulkowski, S.; Surmacz, E. Increased expression of leptin and the leptin receptor as a marker of breast cancer progression: Possible role of obesity-related stimuli. Clin. Cancer Res. Off. J. Am. Assoc. Cancer Res. 2006, 12, 1447-1453. [CrossRef] [PubMed]

15. Ishikawa, M.; Kitayama, J.; Nagawa, H. Enhanced expression of leptin and leptin receptor (OB-R) in human breast cancer. Clin. Cancer Res. Off. J. Am. Assoc. Cancer Res. 2004, 10, 4325-4331. [CrossRef] [PubMed]

16. Saxena, N.K.; Sharma, D.; Ding, X.; Lin, S.; Marra, F.; Merlin, D.; Anania, F.A. Concomitant activation of the JAK/STAT, PI3K/AKT, and ERK signaling is involved in leptin-mediated promotion of invasion and migration of hepatocellular carcinoma cells. Cancer Res. 2007, 67, 2497-2507. [CrossRef]

17. Sharma, D.; Saxena, N.K.; Vertino, P.M.; Anania, F.A. Leptin promotes the proliferative response and invasiveness in human endometrial cancer cells by activating multiple signal-transduction pathways. Endocr. Relat. Cancer 2006, 13, 629-640. [CrossRef]

18. Carino, C.; Olawaiye, A.B.; Cherfils, S.; Serikawa, T.; Lynch, M.P.; Rueda, B.R.; Gonzalez, R.R. Leptin regulation of proangiogenic molecules in benign and cancerous endometrial cells. Int. J. Cancer 2008, 123, 2782-2790. [CrossRef]

19. Chen, C.; Chang, Y.C.; Liu, C.L.; Liu, T.P.; Chang, K.J.; Guo, I.C. Leptin induces proliferation and anti-apoptosis in human hepatocarcinoma cells by up-regulating cyclin D1 and down-regulating Bax via a Janus kinase 2-linked pathway. Endocr. Relat. Cancer 2007, 14, 513-529. [CrossRef]

20. Gao, R.; Kim, C.; Sei, E.; Foukakis, T.; Crosetto, N.; Chan, L.K.; Srinivasan, M.; Zhang, H.; Meric-Bernstam, F.; Navin, N. Nanogrid single-nucleus RNA sequencing reveals phenotypic diversity in breast cancer. Nat. Commun. 2017, 8, 228. [CrossRef]

21. Kim, C.; Gao, R.; Sei, E.; Brandt, R.; Hartman, J.; Hatschek, T.; Crosetto, N.; Foukakis, T.; Navin, N.E. Chemoresistance Evolution in Triple-Negative Breast Cancer Delineated by Single-Cell Sequencing. Cell 2018, 173, 879-893. [CrossRef] [PubMed]

22. Azizi, E.; Carr, A.J.; Plitas, G.; Cornish, A.E.; Konopacki, C.; Prabhakaran, S.; Nainys, J.; Wu, K.; Kiseliovas, V.; Setty, M.; et al. Single-Cell Map of Diverse Immune Phenotypes in the Breast Tumor Microenvironment. Cell 2018, 174, 1293-1308. [CrossRef] [PubMed]

23. Chung, W.; Eum, H.H.; Lee, H.O.; Lee, K.M.; Lee, H.B.; Kim, K.T.; Ryu, H.S.; Kim, S.; Lee, J.E.; Park, Y.H.; et al. Single-cell RNA-seq enables comprehensive tumour and immune cell profiling in primary breast cancer. Nat. Commun. 2017, 8, 15081. [CrossRef] [PubMed]

24. Peng, S.; Hebert, L.L.; Eschbacher, J.M.; Kim, S. Single-Cell RNA Sequencing of a Postmenopausal Normal Breast Tissue Identifies Multiple Cell Types That Contribute to Breast Cancer. Cancers 2020, 12, 3639. [CrossRef] [PubMed]

25. Uhlen, M.; Bjorling, E.; Agaton, C.; Szigyarto, C.A.; Amini, B.; Andersen, E.; Andersson, A.C.; Angelidou, P.; Asplund, A.; Asplund, C.; et al. A human protein atlas for normal and cancer tissues based on antibody proteomics. Mol. Cell. Proteom. Mcp 2005, 4, 1920-1932. [CrossRef]

26. Mhaidat, N.M.; Alzoubi, K.H.; Kubas, M.A.; Banihani, M.N.; Hamdan, N.; Al-Jaberi, T.M. High levels of leptin and nonhigh molecular weight-adiponectin in patients with colorectal cancer: Association with chemotherapy and common genetic polymorphisms. Biomed. Rep. 2021, 14, 13. [CrossRef] [PubMed]

27. Maroni, P.; Luzzati, A.; Perrucchini, G.; Cannavo, L.; Bendinelli, P. Leptin, Leptin Receptor, KHDRBS1 (KH RNA Binding Domain Containing, Signal Transduction Associated 1), and Adiponectin in Bone Metastasis from Breast Carcinoma: An Immunohistochemical Study. Biomedicines 2020, 8, 510. [CrossRef] [PubMed]

28. Yu, H.; Pan, R.; Qi, Y.; Zheng, Z.; Li, J.; Li, H.; Ying, J.; Xu, M.; Duan, S. LEPR hypomethylation is significantly associated with gastric cancer in males. Exp. Mol. Pathol. 2020, 116, 104493. [CrossRef] [PubMed]

29. Kashiwagi, E.; Abe, T.; Kinoshita, F.; Ushijima, M.; Masaoka, H.; Shiota, M.; Netto, G.J.; Eto, M.; Miyamoto, H. The role of adipocytokines and their receptors in bladder cancer: Expression of adiponectin or leptin is an independent prognosticator. Am. J. Transl. Res. 2020, 12, 3033-3045. [CrossRef]

30. Kamel, H.F.M.; Nassir, A.M.; Al Refai, A.A. Assessment of expression levels of leptin and leptin receptor as potential biomarkers for risk of prostate cancer development and aggressiveness. Cancer Med. 2020, 9, 5687-5696. [CrossRef]

31. Cymbaluk-Ploska, A.; Gargulinska, P.; Chudecka-Glaz, A.; Kwiatkowski, S.; Pius-Sadowska, E.; Machalinski, B. The Suitability of FGF21 and FGF23 as New Biomarkers in Endometrial Cancer Patients. Diagnostics 2020, 10, 414. [CrossRef]

32. Ma, R.; He, Q. A Variant of Leptin Gene Decreases the Risk of Gastric Cancer in Chinese Individuals: Evidence from a Case-Control Study. Pharm. Pers. Med. 2020, 13, 397-404. [CrossRef] [PubMed]

33. Mao, F.; Niu, X.B.; Gu, S.; Ji, L.; Wei, B.J.; Wang, H.B. Investigation of Leptin G19A polymorphism with bladder cancer risk: A case-control study. J. Clin. Lab. Anal. 2020, 34, e23351. [CrossRef] [PubMed]

34. Lin, J.; Xie, Z.; Lan, B.; Guo, Z.; Tang, W.F.; Liu, C.; Zhang, S.; Chen, G.; Guo, F.; Chen, Y. Investigation of Leptin and its receptor (LEPR) for single nucleotide polymorphisms in colorectal cancer: A case-control study involving 2,306 subjects. Am. J. Transl. Res. 2020, 12, 3613-3628. [CrossRef] [PubMed]

35. Ellrott, K.; Bailey, M.H.; Saksena, G.; Covington, K.R.; Kandoth, C.; Stewart, C.; Hess, J.; Ma, S.; Chiotti, K.E.; McLellan, M.; et al. Scalable Open Science Approach for Mutation Calling of Tumor Exomes Using Multiple Genomic Pipelines. Cell Syst. 2018, 6, 271-281. [CrossRef] [PubMed]

36. Gu, F.; Zhang, H.; Yao, L.; Jiang, S.; Lu, H.; Xing, X.; Zhang, C.; Jiang, P.; Zhang, R. Leptin contributes to the taxol chemoresistance in epithelial ovarian cancer. Oncol. Lett. 2019, 18, 561-570. [CrossRef] 
37. Slomian, G.J.; Nowak, D.; Buczkowska, M.; Glogowska-Gruszka, A.; Slomian, S.P.; Roczniak, W.; Janyga, S.; Nowak, P. The role of adiponectin and leptin in the treatment of ovarian cancer patients. Endokrynol. Pol. 2019, 70, 57-63. [CrossRef]

38. Ghasemi, A.; Saeidi, J.; Mohtashami, M.; Hashemy, S.I. Estrogen-independent role of ERalpha in ovarian cancer progression induced by leptin/Ob-Rb axis. Mol. Cell. Biochem. 2019, 458, 207-217. [CrossRef]

39. Ghasemi, A.; Hashemy, S.I.; Aghaei, M.; Panjehpour, M. Leptin induces matrix metalloproteinase 7 expression to promote ovarian cancer cell invasion by activating ERK and JNK pathways. J. Cell. Biochem. 2018, 119, 2333-2344. [CrossRef]

40. Ghasemi, A.; Hashemy, S.I.; Aghaei, M.; Panjehpour, M. RhoA/ROCK pathway mediates leptin-induced uPA expression to promote cell invasion in ovarian cancer cells. Cell. Signal. 2017, 32, 104-114. [CrossRef]

41. Chen, C.; Chang, Y.C.; Lan, M.S.; Breslin, M. Leptin stimulates ovarian cancer cell growth and inhibits apoptosis by increasing cyclin D1 and Mcl-1 expression via the activation of the MEK/ERK1/2 and PI3K/Akt signaling pathways. Int. J. Oncol. 2013, 42, 1113-1119. [CrossRef]

42. Wei, X.; Liu, Y.; Gong, C.; Ji, T.; Zhou, X.; Zhang, T.; Wan, D.; Xu, S.; Jin, P.; Yang, X.; et al. Targeting Leptin as a Therapeutic Strategy against Ovarian Cancer Peritoneal Metastasis. Anti-Cancer Agents Med. Chem. 2017, 17, 1093-1101. [CrossRef] [PubMed]

43. Fiedor, E.; Zajda, K.; Gregoraszczuk, E.L. Leptin Receptor Antagonists' Action on HDAC Expression Eliminating the Negative Effects of Leptin in Ovarian Cancer. Cancer Genom. Proteom. 2018, 15, 329-336. [CrossRef] [PubMed]

44. Riolfi, M.; Ferla, R.; Del Valle, L.; Pina-Oviedo, S.; Scolaro, L.; Micciolo, R.; Guidi, M.; Terrasi, M.; Cetto, G.L.; Surmacz, E. Leptin and its receptor are overexpressed in brain tumors and correlate with the degree of malignancy. Brain Pathol. 2010, 20, 481-489. [CrossRef] [PubMed]

45. Panza, S.; Russo, U.; Giordano, F.; Leggio, A.; Barone, I.; Bonofiglio, D.; Gelsomino, L.; Malivindi, R.; Conforti, F.L.; Naimo, G.D.; et al. Leptin and Notch Signaling Cooperate in Sustaining Glioblastoma Multiforme Progression. Biomolecules 2020, $10,886$. [CrossRef]

46. Martin, R.; Cordova, C.; Gutierrez, B.; Hernandez, M.; Nieto, M.L. A dangerous liaison: Leptin and sPLA2-IIA join forces to induce proliferation and migration of astrocytoma cells. PLoS ONE 2017, 12, e0170675. [CrossRef]

47. Han, G.; Li, Y.; Cao, Y.; Yue, Z.; Zhang, Y.; Wang, L.; Liu, J. Overexpression of leptin receptor in human glioblastoma: Correlation with vasculogenic mimicry and poor prognosis. Oncotarget 2017, 8, 58163-58171. [CrossRef]

48. Ferla, R.; Bonomi, M.; Otvos, L., Jr.; Surmacz, E. Glioblastoma-derived leptin induces tube formation and growth of endothelial cells: Comparison with VEGF effects. BMC Cancer 2011, 11, 303. [CrossRef]

49. Han, G.; Wang, L.; Zhao, W.; Yue, Z.; Zhao, R.; Li, Y.; Zhou, X.; Hu, X.; Liu, J. High expression of leptin receptor leads to temozolomide resistance with exhibiting stem/progenitor cell features in gliobalastoma. Cell Cycle 2013, 12, 3833-3840. [CrossRef]

50. Gantov, M.; Pagnotta, P.; Lotufo, C.; Rindone, G.M.; Riera, M.F.; Calvo, J.C.; Toneatto, J. Beige adipocytes contribute to breast cancer progression. Oncol. Rep. 2021, 45, 317-328. [CrossRef]

51. Delort, L.; Cholet, J.; Decombat, C.; Vermerie, M.; Dumontet, C.; Castelli, F.A.; Fenaille, F.; Auxenfans, C.; Rossary, A.; CaldefieChezet, F. The Adipose Microenvironment Dysregulates the Mammary Myoepithelial Cells and Could Participate to the Progression of Breast Cancer. Front. Cell Dev. Biol. 2020, 8, 571948. [CrossRef]

52. Acheva, A.; Karki, T.; Schaible, N.; Krishnan, R.; Tojkander, S. Adipokine Leptin Co-operates With Mechanosensitive Ca(2 + )-Channels and Triggers Actomyosin-Mediated Motility of Breast Epithelial Cells. Front. Cell Dev. Biol. 2020, 8, 607038. [CrossRef]

53. Li, S.J.; Wei, X.H.; Zhan, X.M.; He, J.Y.; Zeng, Y.Q.; Tian, X.M.; Yuan, S.T.; Sun, L. Adipocyte-Derived Leptin Promotes PAI-1 -Mediated Breast Cancer Metastasis in a STAT3/miR-34a Dependent Manner. Cancers 2020, 12, 3864. [CrossRef]

54. Pham, D.V.; Pun, N.T.; Park, P.H. Autophagy activation and SREBP-1 induction contribute to fatty acid metabolic reprogramming by leptin in breast cancer cells. Mol. Oncol. 2021, 15, 657-678. [CrossRef]

55. Duan, L.; Lu, Y.; Xie, W.; Nong, L.; Jia, Y.; Tan, A.; Liu, Y. Leptin promotes bone metastasis of breast cancer by activating the SDF-1/CXCR4 axis. Aging 2020, 12, 16172-16182. [CrossRef]

56. Gelsomino, L.; Naimo, G.D.; Malivindi, R.; Augimeri, G.; Panza, S.; Giordano, C.; Barone, I.; Bonofiglio, D.; Mauro, L.; Catalano, S.; et al. Knockdown of Leptin Receptor Affects Macrophage Phenotype in the Tumor Microenvironment Inhibiting Breast Cancer Growth and Progression. Cancers 2020, 12, 2078. [CrossRef] [PubMed]

57. Boothby-Shoemaker, W.; Benham, V.; Paithankar, S.; Shankar, R.; Chen, B.; Bernard, J.J. The Relationship between Leptin, the Leptin Receptor and FGFR1 in Primary Human Breast Tumors. Cells 2020, 9, 2224. [CrossRef]

58. Raut, P.K.; Park, P.H. Globular adiponectin antagonizes leptin-induced growth of cancer cells by modulating inflammasomes activation: Critical role of HO-1 signaling. Biochem. Pharmacol. 2020, 180, 114186. [CrossRef] [PubMed]

59. Linares, R.L.; Benitez, J.G.S.; Reynoso, M.O.; Romero, C.G.; Sandoval-Cabrera, A. Modulation of the leptin receptors expression in breast cancer cell lines exposed to leptin and tamoxifen. Sci. Rep. 2019, 9, 19189. [CrossRef] [PubMed]

60. Ding, Y.; Cao, Y.; Wang, B.; Wang, L.; Zhang, Y.; Zhang, D.; Chen, X.; Li, M.; Wang, C. APPL1-Mediating Leptin Signaling Contributes to Proliferation and Migration of Cancer Cells. PLoS ONE 2016, 11, e0166172. [CrossRef] [PubMed]

61. Chen, L.; Shi, Y.; Jiang, C.Y.; Sun, Q.; Wang, L.X.; Dai, G.H. Expression of leptin and leptin receptor in hepatocellular carcinoma and the clinicopathological significance. J. South Med. Univ. 2011, 31, 830-833.

62. Ribatti, D.; Belloni, A.S.; Nico, B.; Di Comite, M.; Crivellato, E.; Vacca, A. Leptin-leptin receptor are involved in angiogenesis in human hepatocellular carcinoma. Peptides 2008, 29, 1596-1602. [CrossRef] [PubMed] 
63. Huang, H.; Zhang, J.; Ling, F.; Huang, Y.; Yang, M.; Zhang, Y.; Wei, Y.; Zhang, Q.; Wang, H.; Song, L.; et al. Leptin Receptor (LEPR) promotes proliferation, migration, and invasion and inhibits apoptosis in hepatocellular carcinoma by regulating ANXA7. Cancer Cell Int. 2021, 21, 4. [CrossRef] [PubMed]

64. Ho, Y.; Wang, S.H.; Chen, Y.R.; Li, Z.L.; Chin, Y.T.; Yang, Y.S.H.; Wu, Y.H.; Su, K.W.; Chu, H.R.; Chiu, H.C.; et al. Leptin-derived peptides block leptin-induced proliferation by reducing expression of pro-inflammatory genes in hepatocellular carcinoma cells Food Chem. Toxicol. Int. J. Publ. Br. Ind. Biol. Res. Assoc. 2019, 133, 110808. [CrossRef]

65. Thompson, K.J.; Lau, K.N.; Johnson, S.; Martinie, J.B.; Iannitti, D.A.; McKillop, I.H.; Sindram, D. Leptin inhibits hepatocellular carcinoma proliferation via p38-MAPK-dependent signalling. Hpb Off. J. Int. Hepato Pancreato Biliary Assoc. 2011, 13, 225-233. [CrossRef] [PubMed]

66. Meerson, A.; Yehuda, H. Leptin and insulin up-regulate miR-4443 to suppress NCOA1 and TRAF4, and decrease the invasiveness of human colon cancer cells. BMC Cancer 2016, 16, 882. [CrossRef] [PubMed]

67. Song, N.Y.; Lee, Y.H.; Na, H.K.; Baek, J.H.; Surh, Y.J. Leptin induces SIRT1 expression through activation of NF-E2-related factor 2: Implications for obesity-associated colon carcinogenesis. Biochem. Pharmacol. 2018, 153, 282-291. [CrossRef]

68. Milosevic, V.S.; Vukmirovic, F.C.; Krstic, M.S.; Zindovic, M.M.; Lj Stojanovic, D.; Jancic, S.A. Involvement of leptin receptors expression in proliferation and neoangiogenesis in colorectal carcinoma. J. Off. J. Balk. Union Oncol. 2015, 20, 100-108.

69. Vuletic, M.S.; Milosevic, V.S.; Jancic, S.A.; Zujovic, J.T.; Krstic, M.S.; Vukmirovic, F.C. Clinical significance of Leptin receptor (LEPR) and Endoglin (CD105) expressions in colorectal adenocarcinoma. J. Off. J. Balk. Union Oncol. 2019, 24, $2448-2457$.

70. Higurashi, T.; Endo, H.; Uchiyama, T.; Uchiyama, S.; Yamada, E.; Ohkubo, H.; Sakai, E.; Takahashi, H.; Maeda, S.; Wada, K.; et al. Conditional knockout of the leptin receptor in the colonic epithelium revealed the local effects of leptin receptor signaling in the progression of colonic tumors in mice. Carcinogenesis 2014, 35, 2134-2141. [CrossRef]

71. Shahraki, N.; Mehrabian, A.; Amiri-Darban, S.; Moosavian, S.A.; Jaafari, M.R. Preparation and characterization of PEGylated liposomal Doxorubicin targeted with leptin-derived peptide and evaluation of their anti-tumor effects, in vitro and in vivo in mice bearing C26 colon carcinoma. Colloids Surf. Biointerfaces 2021, 200, 111589. [CrossRef]

72. Darban, S.A.; Nikoofal-Sahlabadi, S.; Amiri, N.; Kiamanesh, N.; Mehrabian, A.; Zendehbad, B.; Gholizadeh, Z.; Jaafari, M.R. Targeting the leptin receptor: To evaluate therapeutic efficacy and anti-tumor effects of Doxil, in vitro and in vivo in mice bearing C26 colon carcinoma tumor. Colloids Surf. Biointerfaces 2018, 164, 107-115. [CrossRef] [PubMed]

73. Xu, Y.J.; Shao, Y.F.; Zhao, X.; Geng, Y.T.; Wang, K.; Yin, Y.M. Expression and clinical significance of leptin, the functional receptor of leptin (OB-Rb) and HER-2 in non-small-cell lung cancer: A retrospective analysis. J. Cancer Res. Clin. Oncol. 2011, 137, 1841-1848. [CrossRef]

74. Karatas, F.; Yalcin, B.; Sahin, S.; Akbulut, H.; Utkan, G.; Demirkazik, A.; Icli, F. The significance of serum leptin level in patients with early stage nonsmall cell lung cancer. J. Cancer Res. Ther. 2017, 13, 204-207. [CrossRef] [PubMed]

75. Feng, H.L.; Guo, P.; Wang, J.; Liu, Q.Y.; Xu, J.F.; Yang, H.C.; Zhang, J.M. Association of the expression of leptin and leptin receptor with bone metastasis in pulmonary adenocarcinoma. Chin. J. Oncol. 2016, 38, 840-844. [CrossRef]

76. Xu, M.; Cao, F.L.; Li, N.; Gao, X.; Su, X.; Jiang, X. Leptin induces epithelial-to-mesenchymal transition via activation of the ERK signaling pathway in lung cancer cells. Oncol. Lett. 2018, 16, 4782-4788. [CrossRef] [PubMed]

77. Jiang, C.; Zhao, H.; Yang, B.; Sun, Z.; Li, X.; Hu, X. lnc-REG3G-3-1/miR-215-3p Promotes Brain Metastasis of Lung Adenocarcinoma by Regulating Leptin and SLC2A5. Front. Oncol. 2020, 10, 1344. [CrossRef] [PubMed]

78. Wang, F.; Zhang, L.; Sai, B.; Wang, L.; Zhang, X.; Zheng, L.; Tang, J.; Li, G.; Xiang, J. BMSC-derived leptin and IGFBP2 promote erlotinib resistance in lung adenocarcinoma cells through IGF-1R activation in hypoxic environment. Cancer Biol. Ther. 2020, 21, 61-71. [CrossRef]

79. Lai, Q.; Sun, Y. Human leptin protein induces proliferation of A549 cells via inhibition of PKR-like ER kinase and activating transcription factor-6 mediated apoptosis. Yonsei Med. J. 2013, 54, 1407-1415. [CrossRef]

80. Li, F.; Zhao, S.; Guo, T.; Li, J.; Gu, C. The Nutritional Cytokine Leptin Promotes NSCLC by Activating the PI3K/AKT and MAPK/ERK Pathways in NSCLC Cells in a Paracrine Manner. Biomed. Res. Int. 2019, 2019, 2585743. [CrossRef]

81. Ren, H.; Jia, L.; Zhao, T.; Zhang, H.; Chen, J.; Yang, S.; Liu, J.; Yu, M.; Hao, J. Hypoxia inducible factor (HIF)-1alpha directly activates leptin receptor (Ob-R) in pancreatic cancer cells. Cancer Lett. 2014, 354, 172-180. [CrossRef] [PubMed]

82. Xu, Y.; Tan, M.; Tian, X.; Zhang, J.; Chen, J.; Xu, W.; Sheng, H. Leptin receptor mediates the proliferation and glucose metabolism of pancreatic cancer cells via AKT pathway activation. Mol. Med. Rep. 2020, 21, 945-952. [CrossRef] [PubMed]

83. Fan, Y.; Gan, Y.; Shen, Y.; Cai, X.; Song, Y.; Zhao, F.; Yao, M.; Gu, J.; Tu, H. Leptin signaling enhances cell invasion and promotes the metastasis of human pancreatic cancer via increasing MMP-13 production. Oncotarget 2015, 6, 16120-16134. [CrossRef] [PubMed]

84. Harbuzariu, A.; Rampoldi, A.; Daley-Brown, D.S.; Candelaria, P.; Harmon, T.L.; Lipsey, C.C.; Beech, D.J.; Quarshie, A.; Ilies, G.O.; Gonzalez-Perez, R.R. Leptin-Notch signaling axis is involved in pancreatic cancer progression. Oncotarget 2017, 8, 7740-7752. [CrossRef] [PubMed]

85. Karabulut, S.; Afsar, C.U.; Karabulut, M.; Alis, H.; Erturk, K.; Karaman, S.; Kones, O.; Bilgin, E.; Tas, F. Serum leptin levels may have diagnostic and predictive roles in patients with pancreatic adenocarcinoma treated with gemcitabine-based chemotherapy. J. Off. J. Balk. Union Oncol. 2016, 21, 895-902.

86. Ma, L.; Fan, Z.; Du, G.; Wang, H. Leptin-elicited miRNA-342-3p potentiates gemcitabine resistance in pancreatic ductal adenocarcinoma. Biochem. Biophys. Res. Commun. 2019, 509, 845-853. [CrossRef] [PubMed] 
87. Harbuzariu, A.; Gonzalez-Perez, R.R. Leptin-Notch axis impairs 5-fluorouracil effects on pancreatic cancer. Oncotarget 2018, 9 , 18239-18253. [CrossRef] [PubMed]

88. Mendonsa, A.M.; Chalfant, M.C.; Gorden, L.D.; VanSaun, M.N. Modulation of the leptin receptor mediates tumor growth and migration of pancreatic cancer cells. PLoS ONE 2015, 10, e0126686. [CrossRef] [PubMed]

89. Xu, C.J.; Dong, L.L.; Kang, X.L.; Li, Z.M.; Zhang, H.Y. Leptin promotes proliferation and inhibits apoptosis of prostate cancer cells by regulating ERK1/2 signaling pathway. Eur. Rev. Med Pharmacol. Sci. 2020, 24, 8341-8348. [CrossRef]

90. Gorrab, A.; Pagano, A.; Ayed, K.; Chebil, M.; Derouiche, A.; Kovacic, H.; Gati, A. Leptin Promotes Prostate Cancer Proliferation and Migration by Stimulating STAT3 Pathway. Nutr. Cancer 2020, 10, 1-11. [CrossRef]

91. Zou, H.; Liu, Y.; Wei, D.; Wang, T.; Wang, K.; Huang, S.; Liu, L.; Li, Y.; Ge, J.; Li, X.; et al. Leptin promotes proliferation and metastasis of human gallbladder cancer through OB-Rb leptin receptor. Int. J. Oncol. 2016, 49, 197-206. [CrossRef] [PubMed]

92. Yu, W.; Cao, D.D.; Li, Q.B.; Mei, H.L.; Hu, Y.; Guo, T. Adipocytes secreted leptin is a pro-tumor factor for survival of multiple myeloma under chemotherapy. Oncotarget 2016, 7, 86075-86086. [CrossRef] [PubMed]

93. Yang, W.H.; Chang, A.C.; Wang, S.W.; Wang, S.J.; Chang, Y.S.; Chang, T.M.; Hsu, S.K.; Fong, Y.C.; Tang, C.H. Leptin promotes VEGF-C production and induces lymphangiogenesis by suppressing miR-27b in human chondrosarcoma cells. Sci. Rep. 2016, 6, 28647. [CrossRef] [PubMed]

94. Yang, W.H.; Chen, J.C.; Hsu, K.H.; Lin, C.Y.; Wang, S.W.; Wang, S.J.; Chang, Y.S.; Tang, C.H. Leptin increases VEGF expression and enhances angiogenesis in human chondrosarcoma cells. Biochim. Biophys. Acta 2014, 1840, 3483-3493. [CrossRef] [PubMed]

95. Zhang, Y.; Liu, L.; Li, C.; Ai, H. Correlation analysis between the expressions of leptin and its receptor (ObR) and clinicopathology in endometrial cancer. Cancer Biomark. Sect. A Dis. Markers 2014, 14, 353-359. [CrossRef]

96. Wu, X.; Yan, Q.; Zhang, Z.; Du, G.; Wan, X. Acrp30 inhibits leptin-induced metastasis by downregulating the JAK/STAT3 pathway via AMPK activation in aggressive SPEC-2 endometrial cancer cells. Oncol. Rep. 2012, 27, 1488-1496. [CrossRef] [PubMed]

97. Vuletic, M.; Jancic, S.; Milenkovic, S.; Paunovic, M.; Milicic, B.; Jancic, N.; Perunicic, B.; Slovic, Z. Clinical-pathological significance of leptin receptor (LEPR) expression in squamous cell carcinoma of the skin. Pathol. Res. Pract. 2020, 216, 153111. [CrossRef] [PubMed]

98. Oba, J.; Wei, W.; Gershenwald, J.E.; Johnson, M.M.; Wyatt, C.M.; Ellerhorst, J.A.; Grimm, E.A. Elevated Serum Leptin Levels are Associated With an Increased Risk of Sentinel Lymph Node Metastasis in Cutaneous Melanoma. Medicine 2016, 95 , e3073. [CrossRef] [PubMed]

99. Amjadi, F.; Mehdipoor, R.; Zarkesh-Esfahani, H.; Javanmard, S.H. Leptin serves as angiogenic/mitogenic factor in melanoma tumor growth. Adv. Biomed. Res. 2016, 5, 127. [CrossRef] [PubMed]

100. Zhang, L.; Yuan, Q.; Li, M.; Chai, D.; Deng, W.; Wang, W. The association of leptin and adiponectin with hepatocellular carcinoma risk and prognosis: A combination of traditional, survival, and dose-response meta-analysis. BMC Cancer 2020, $20,1167$. [CrossRef] [PubMed]

101. Perumal, K.; Mun, K.S.; Yap, N.Y.; Razack, A.H.A.; Gobe, G.C.; Ong, T.A.; Kuppusamy, S.; Rajandram, R. A Study on the Immunohistochemical Expressions of Leptin and Leptin Receptor in Clear Cell Renal Cell Carcinoma. Biomed. Res. Int. 2020, 2020, 3682086. [CrossRef] [PubMed]

102. Kumar, J.; Fang, H.; McCulloch, D.R.; Crowley, T.; Ward, A.C. Leptin receptor signaling via Janus kinase 2/Signal transducer and activator of transcription 3 impacts on ovarian cancer cell phenotypes. Oncotarget 2017, 8, 93530-93540. [CrossRef]

103. Sultana, R.; Kataki, A.C.; Borthakur, B.B.; Basumatary, T.K.; Bose, S. Imbalance in leptin-adiponectin levels and leptin receptor expression as chief contributors to triple negative breast cancer progression in Northeast India. Gene 2017, 621, 51-58. [CrossRef]

104. Lee, Y.C.; Wu, W.J.; Lin, H.H.; Li, W.M.; Huang, C.N.; Hsu, W.C.; Chang, L.L.; Li, C.C.; Yeh, H.C.; Li, C.F.; et al. Prognostic Value of Leptin Receptor Overexpression in Upper Tract Urothelial Carcinomas in Taiwan. Clin. Genitourin. Cancer 2017, 15, e653-e659. [CrossRef] [PubMed]

105. Khabaz, M.N.; Abdelrahman, A.; Butt, N.; Damnhory, L.; Elshal, M.; Aldahlawi, A.M.; Ashoor, S.; Al-Maghrabi, B.; Dobson, P.; Brown, B.; et al. Immunohistochemical staining of leptin is associated with grade, stage, lymph node involvement, recurrence, and hormone receptor phenotypes in breast cancer. BMC Women's Health 2017, 17, 105. [CrossRef] [PubMed]

106. Mendoza-Perez, J.; Gu, J.; Herrera, L.A.; Tannir, N.M.; Zhang, S.; Matin, S.; Karam, J.A.; Wood, C.G.; Wu, X. Prognostic significance of promoter $\mathrm{CpG}$ island methylation of obesity-related genes in patients with nonmetastatic renal cell carcinoma. Cancer 2017, 123, 3617-3627. [CrossRef] [PubMed]

107. Uhlen, M.; Fagerberg, L.; Hallstrom, B.M.; Lindskog, C.; Oksvold, P.; Mardinoglu, A.; Sivertsson, A.; Kampf, C.; Sjostedt, E.; Asplund, A.; et al. Proteomics. Tissue-based map of the human proteome. Science 2015, 347, 1260419. [CrossRef] [PubMed]

108. Uhlen, M.; Oksvold, P.; Fagerberg, L.; Lundberg, E.; Jonasson, K.; Forsberg, M.; Zwahlen, M.; Kampf, C.; Wester, K.; Hober, S.; et al. Towards a knowledge-based Human Protein Atlas. Nat. Biotechnol. 2010, 28, 1248-1250. [CrossRef] [PubMed]

109. Thul, P.J.; Akesson, L.; Wiking, M.; Mahdessian, D.; Geladaki, A.; Ait Blal, H.; Alm, T.; Asplund, A.; Bjork, L.; Breckels, L.M.; et al. A subcellular map of the human proteome. Science 2017, 356, eaal3321. [CrossRef] [PubMed]

110. Uhlen, M.; Zhang, C.; Lee, S.; Sjostedt, E.; Fagerberg, L.; Bidkhori, G.; Benfeitas, R.; Arif, M.; Liu, Z.; Edfors, F.; et al. A pathology atlas of the human cancer transcriptome. Science 2017, 357, eaan2507. [CrossRef] [PubMed]

111. Gyorffy, B.; Schafer, R. Meta-analysis of gene expression profiles related to relapse-free survival in 1,079 breast cancer patients. Breast Cancer Res. Treat. 2009, 118, 433-441. [CrossRef] [PubMed] 